\title{
FIELD OF OPTIMIZATION OF FINANCIAL-ECONOMIC ACCOUNTING IN MODERN CONDITIONS
}

\section{НАПРЯМКИ ОПТИМІЗАЦІЇ ФІНАНСОВО-ЕКОНОМІЧНОГО РАХІВНИЦТВА В СУЧАСНИХ УМОВАХ}

\section{Irina Varenik ${ }^{1}$ \\ Irina Prigara ${ }^{2}$}

DOI: https://doi.org/10.30525/978-9934-588-15-0-25

Abstract. In the context of European integration processes for Ukraine and its economy, under the current conditions of development, there was an objective need for corresponding changes in the system of macroeconomic statistics and accounting. In accordance with the provisions of the concept of transition of national statistics to international standards, Ukraine has introduced a standard system of accounts and accounting in the countries of the world. The relevance of the research topic is determined by the need to improve the system of national accounting of the country and adapt international recommendations for its construction and use taking into account the current socio-economic conditions of our country, as well as updating the existing information base of calculations of final household consumption expenditures. The purpose of the study is to develop scientific and practical recommendations for the improvement and adaptation of international recommendations on the use, taking into account the current socio-economic conditions in Ukraine, the existing information base for calculating final household consumption costs. The subject of the study is macroeconomic measurements as a tool for improving the economic mechanism of society, mechanisms for the use of information resources in the system of national micro- and macroeconomic regulation. The information base is scientific monographic literature, published by

\footnotetext{
${ }^{1}$ Candidate of Economic Sciences, Senior Lecturer, Department of Economics and Management, Shostka Institute, Sumy State University, Ukraine

${ }^{2}$ Candidate of Economic Sciences, Senior Lecturer, Department of Economics and Management, Shostka Institute, Sumy State University,Ukraine 
domestic and foreign authors, scientific articles, laws and regulations, laws and regulations of Ukraine use of information resources, official statistical materials, production and financial and economic reporting activities The following methods were used in the study: logical-dialectical, structural-logical and semantic analysis (to clarify and streamline the terminology in the conceptual apparatus), critical analysis (in the allocation of the main directions of scientific directions problems), the methods of factor analysis of cause and effect relationships, by which the relationship between the final results of GDP calculation in the non-financial corporations sector was studied rationale and primary sources of data, the financial method in the study of initial financial statements. Thus, the proposals for improvement of economic accounting are substantiated in the work, namely: taking into account by individual households students who live separately from their parents during the school year (in dormitories or renting housing) and are therefore forced to independently manage (including spend resources, including eat separately). In Ukraine, their number is 430,000 (or about $1 \%$ of the total population). But in a sample household survey, they are not considered as a separate household. Unresolved deficiencies in accounting are the prospect of further scientific research.

\section{1. Ветуп}

Актуальність теми дослідження визначається необхідністю удосконалення системи національного обліку країни та адаптації міжнародних рекомендацій щодо іiї побудови і використання з врахуванням сучасних соціально-економічних умов нашої країни, а також актуалізації існуючої інформаційної бази розрахунків кінцевих споживчих витрат домогосподарств. Метою дослідження є розробка науково-практичних рекомендацій з удосконалення та адаптації міжнародних рекомендацій щодо використання, з врахуванням сучасних соціально-економічних умов в Україні, існуючої інформаційної бази розрахунків кінцевих споживчих витрат домогосподарств.

Відповідно до поставленої мети вирішувались наступні взаємопов'язані теоретико-методичні та науково-практичні задачі:

- визначення місця кінцевих споживчих витрат домогосподарств як основного макроекономічного показника, що характеризує життєвий рівень населення; 
- визначення величини і структури кінцевих споживчих витрат домогосподарств за допомогою грунтовного аналізу існуючої інформаційно-статистичної бази, яка використовується у практиці України;

- обгрунтування методики і особливостей статистичного порівняння кінцевих споживчих витрат населення (домогосподарств) в Україні і зарубіжних країнах в межах Проекту міжнародних порівнянь ВВП.

Об'єктом дослідження є методико-статистичні підходи та інструментарій оцінки кінцевих споживчих витрат домогосподарств.

Предметом дослідження є кінцеві споживчі витрати домогосподарств України.

Науковою новизною одержаних результатів дослідження $є$ результати, що одержані особисто авторами і полягають у розробці наукових засад формування і використання облікових даних національного рахівництва як інструмента для оцінки кінцевих споживчих витрат домогосподарств, а саме одержано економічне обгрунтування інституційної природи кінцевих споживчих витрат через характеристику їх пізнавальних властивостей і макроекономічного значення.

3 огляду на це, питання адаптації міжнародних стандартів національного обліку на сучасні умови, привертають увагу праці науковців різних країн. Серед авторів слід насамперед, відзначити В. Хантке, I. Менге, Б.Т. Рябушкіна, Г.Д. Кулагіну, Т.О. Хоменко. В Україні ці питання розглядались в працях В.П. Анісімова, С.С. Герасименка, О.М. Гладуна, А.В. Головача, О.П. Романюка та інших. Також ці питання висвітлювались в публікаціях співробітників Державного комітету статистики України - В.А. Головка, І.А. Іванченка, О.Ю. Беглової. Проте, на сьогодні далеко не всі питання можна вважати розв'язаними, зокрема, у сфері вивчення розподільчої структури валового внутрішнього продукту (ВВП). Значні ускладнення залишаються зі статистичними проблемами визначення абсолютної величини, структури і темпів змін його найбільш вагомої частини - кінцевих споживчих витрат домогосподарств.

\section{2. Методологічні засади інтелектуальної економіки}

Проблеми структури, збалансованості і рівномірного зростання національної економіки та іiї складових (галузей, інституційних секторів, регіонів) завжди посідали чільне місце у світовій та вітчизняній 
економічній науці. Нагальність завдань комплексного опрацювання методологічних засад ринкової трансформації національної економіки незаперечно підтверджує актуальність нового, інституціонального підходу в економічній науці.

Особливої ваги цей підхід набуває для визначення стратегії переходу інтелектуальної економіки до євроінтеграційної системи. Адже саме інститути виступають провідниками та глибинною субстанцією ринкових відносин в економіці. Особливого значення набуває історичний досвід інституціональних підходів до питань удосконалення ринкової економіки таких видатних українських учених, як М. Бунге, Г. Симоненко, та інших, що працювали у напрямі політичної економії кінця XIX - початку XX ст. Значний інтерес до системних досліджень структури національної економіки, господарського механізму і його інституційного регулювання виникає після виходу фундаментальних досліджень Дж. Кейнса, Р. Фріша, Я. Тінбергена, Р. Стоуна, В. Леонтьєва та інших.

У тому ж напрямку з початку свого заснування Організація Об'єднаних Націй розпочинає роботи, спрямовані на проведення економічного аналізу становища різних країн за єдиною методикою, i, таким чином, сприяє систематичним дослідженням інституціонального інструментарію макроекономічних вимірювань - національного рахівництва, структури національних рахунків, підтримки економічної рівноваги та стабільності економічного механізму країни.

В Україні одним із нагальних завдань, що стоять перед економічною наукою, є дослідження значення, місця, ролі та принципів ведення рахівництва, застосування Системи національних рахунків як інструментарію дослідження економічного механізму країни з метою відповідності загальноприйнятій в європейській та міжнародній практиці системі обліку і статистики.

СНР є важливим інституціональним інструментарієм дослідження економічного механізму країни, що дає ключ до розуміння взаємозв'язку економіки на мікрорівні (діяльність малих економічних одиниць - таких, як сімейні господарства, ділові фірми і урядові установи) і загальноекономічних явищ (інфляція, зайнятість, економічне зростання, яке включає створення національного і внутрішнього продукту). Також СНР створює міцну основу для оцінки управлінських 
рішень, що приймаються у сфері економічного механізму країни, окремих законодавчих актів 3 точки зору їх впливу на великомасштабні економічні явища в їх взаємозв'язку у сучасній економіці [1].

У цьому контексті особливо очевидною $\epsilon$ необхідність по-новому осмислити ті сталі зв'язки, що склалися в ході економічного розвитку країни, міжнародного соціально-економічного буття та співробітництва, а також нові детермінанти розвитку, які визначають параметри соціально-економічної діяльності, враховуючи зростання значення програмно-цільових факторів розвитку, що опосередковуються у діяльності різноманітних інститутів суспільства. Це, природно, потребує кардинальної зміни розуміння всього економічного обороту економічного механізму, соціально-економічних процесів, їх обліку i аналізу. В цілому світовий досвід використання СНР в системі господарювання дає позитивну оцінку обліку господарських операцій на всіх рівнях економіки.

\section{3. Вплив економічної системи на макроекономічний облік}

Система національних рахунків $\epsilon$ важливим елементом у сфері оцінювання ефективності економічної системи та можливостей іiї інтеграції в європейському просторі. Національні рахунки $є$ засобом аналізу, оцінювання, планування та прогнозування економічних результатів сфери економічного механізму країни. Суспільний розвиток, зміна економічних систем вимагає удосконалення усіх сфер господарювання [2].

Перехід України відносини євроінтеграції потребує докорінного удосконалення процесу макроекономічних вимірювань згідно світових вимог. Але зробити це миттєво неможливо. Цей процес має тривалий еволюційний характер. Для того, щоб прискорити його, не порушуючи внутрішньої сутності, необхідно засвоїти практичний досвід, накопичений країнами з розвинутою економікою, та запровадити міжнародні стандарти обліку і статистики, з урахуванням позитивного національного досвіду.

Аналіз праць вітчизняних та зарубіжних дослідників засвідчує, що на сьогоднішній день в економічній науці сформовано широку концептуальну матрицю теоретичної репрезентації трансформаційних процесів економіки. Господарська діяльність весь час зазнає змін згідно розвитку економічних систем. На думку сучасних дослідни- 
ків, адекватному сприйняттю багатьох понять, що позначають соціально-економічні зміни, нерідко заважають міфи та ідейно-політичні стереотипи, притаманні відповідним епохам [2]. Перехід від однієї економічної системи до іншої характеризується відповідними змінами у сфері господарських відносин, змінами методик обліку результатів господарювання. Оцінка наслідків трансформаційних процесів в економіці пояснює необхідність змін моделей національного рахівництва відповідно діючій економічній системі з метою якісного ііі оцінювання.

До цього часу серед вітчизняних та зарубіжних науковців існує проблема розуміння самої сутності трансформації економічних систем, що заважає досконалості рахівництва та обліку результатів господарювання. Палітра існуючих підходів є досить широкою: від трактування трансформацій як руху, що описується певними змінами окремих характеристик макроекономічних систем (різної інтенсивності, глибини, тривалості), безперервної зміни станів, розвитку, до визначення системних перетворень як дискретного перебігу радикальних трансформацій, а не процесу якісних змін [3].

Найзагальнішим поняттям, яке відображає трансформацію економічної системи, є іiі розвиток - поступовий, спрямований та закономірний процес взаємопов'язаних кількісних та якісних перетворень [2], результатом якого і $є$ сучасна економіка. Сучасна економічна література здебільшого однобічно тлумачить категорію «економічна система». Так, у «Великому економічному словнику» вона характеризується як «структура економічного простору, за якої приватна система управляється ринковим механізмом, а суспільні інститути і уряд, спираючись на ринковий механізм, впливають на економіку шляхом директив і податкової політики» [2]. У «Сучасному економічному словнику» така економіка розглядається як економіка країни, у якій поєднуються ознаки ринкової та соціальної економічних систем.

Українські економісти визначають сучасну економіку як «економічну систему, в якій регулювання економічних процесів здійснюється як ринком, так і державою без вирішальної переваги одного 3 них» [3]. Колектив англійських вчених стверджує, що така економіка $\epsilon$ системою, в якій поєднується наявність конкуруючих приватних підприємств $з$ певним ступенем централізованого регулювання [2]. Таким чином, вітчизняна сучасна економіка - це модель соціально-економіч- 
ного розвитку, що передбачає поєднання приватної і державної типів і форм економічної власності, державного, монополістичного і ринкового механізмів регулювання, проведення інституційно-соціальних реформ та національного економічного планування з метою побудови ефективного механізму.

Однією із головних цілей трансформації української економіки є становлення конкурентно-спроможної ринкової структури із збалансованим розвитком державного та приватного секторів, підвищення якості життя і добробуту народу. У цьому напрямі результати трансформаційних процесів мають активізувати можливість моніторингу господарських операцій та їх наслідків, відображати їх в найповнішій мірі, що, насамперед, базується на необхідності реформування національного рахівництва як складової економічного механізму. Особливості розвитку економіки, формування соціально-орієнтованої економіки вимагають удосконалення процесу обліку операцій господарського механізму країни.

Кінцевою метою трансформації перехідного суспільства в Україні $\epsilon$ створення умов для переходу до ефективної економічної системи, яка б забезпечувала оптимальні темпи зростання ВВП та високий життєвий рівень населення [4]. Проблема нашої економіки, в першу чергу, полягає не в тому, щоб швидко перейти до європейських засад, а в переході від економіки, що базується на екстенсивному способі розвитку, шляхом інтенсифікації виробництва до економіки, основу якої складають найновіші технології, високий рівень науки в поєднанні 3 високим загальносвітовим рівнем. Саме на цій основі ми повинні побудувати новий економічний механізм та давати оцінку його дієвості, застосовуючи принципи національного рахівництва.

Економіка являє собою сукупність процесів виробництва, розподілу, обміну і накопичення матеріальних благ і послуг [4]. Трудова діяльність в суспільному виробництві здійснюється в порядку повної взаємодії всіх галузей виробництва, усіх підприємств і організацій. Оскільки виробництво здійснюється спільно і має суспільний характер, то воно здійснюється на основі цілеспрямованої організації і керування. Керування економікою характеризується цілеспрямованим, упорядкованим впливом на процес суспільної праці за допомогою участі домогосподарств в економічному механізмі [3]. 
Поняття економічного механізму в економічній літературі є дискусійним. Одні автори ототожнюють його із системою керування економікою, інші - розглядають як комплекс господарських і організаційних принципів. Існує думка, що економічний механізм - це сукупність форм і методів господарювання. Також економічний механізм вчені розглядають як узяту в єдності всю сукупність економічних, організаційно-правових, морально-політичних та інших засобів впливу держави на суспільно-виробничі відносини, на процес виробництва [4]. В «Економічній енциклопедії» економічний механізм визначається як «сукупність економічних структур, інститутів, форм і методів господарювання, завдяки яким здійснюється ув'язування і узгодження суспільних, групових і приватних інтересів, забезпечується функціонування й розвиток економіки [3]. Очевидною $є$ потреба організації та підтримки обліку господарських операцій економічного механізму як способу організації суспільного виробництва із властивими йому формами і методами, економічними стимулами і правовими нормами.

Таким чином, економічний механізм - це сукупність організаційних структур, конкретних форм і методів керування, а також правових норм, за допомогою яких реалізуються діючі у конкретних умовах економічні закони, процес відтворення [2]. Економічний механізм - це система управління народним господарством за допомогою сукупності основних форм, методів і важелів управління народним господарством шляхом використання економічних законів, розв'язання суперечностей економічної системи, реалізації відносин власності, а також розвитку людини та узгодження найважливіших інтересів суспільства [3].

Фінансово-економічне рахівництво в системі економічного механізму застосовується в потребах у сфері виробничих відносин між державою та суб'єктами господарювання, а також між суб' єктами ринкової економіки з приводу використання різних форм і методів управління господарством та регулювання насамперед відносин в інтеграційному процесі національної економіки. Основними елементами економічного механізму є саморегулювання, державне регулювання та наднаціональне регулювання. У процесі постійної взаємодії елементів продуктивних сил, техніко-економічних, організаційно-економічних і виробничих відносин, які безпосередньо належать до економічного механізму, він формується як відносно відособлений елемент економічної системи [3]. 
Таким чином, економічний механізм - це механізм функціонування економіки, утворений: 1) системою органів керування господарством і безпосередніх виробників - підприємств і об'єднань; 2) системою форм і методів організації і функціонування виробництва; 3) системою господарських зв'язків, що забезпечують обмін результатами діяльності господарських одиниць і досягнення кінцевої мети виробництва.

Соціально-економічна діяльність формує економічний механізм країни, який охоплює мікро- і макросередовище, де існує необхідність обліку та аналізу результатів господарської діяльності. В цілому фінансово-економічний механізм країни представляє систему прямих і зворотних зв'язків, які мають характер інформаційних потоків, управлінських рішень та організаційно-адміністративної діяльності економічних суб'єктів. Ця діяльність базується на відносинах власності, державному законодавстві, державному регулюванні, економічних відносинах, які мають в своїй основі узгодження і підпорядкування економічних інтересів суб'єктів, а також стосується взаємодії виробництва, розподілу, обміну і споживання на всіх рівнях економіки (мікро-, мезо- і макро-) [4].

Проблема формування дієвого фінансово-економічного механізму України в євроінтеграційних умовах лишається невирішеною, перш за все внаслідок відсутності визначення чіткої концепції реформування економіки. Трансформаційна криза економіки України зумовлена непослідовністю практичних заходів реформування, супроводжується недостатньою теоретичною обгрунтованістю.

До нинішнього часу існуючі теорії побудови та розвитку соціально-економічних систем певною мірою систематизовані, але використання досягнень вітчизняної і світової економічної науки в Україні не дало бажаних результатів економічного зростання. Вважаємо, що причина - в непослідовному і фрагментарному використанні базових концепцій економічного механізму. Поспіхом було обране рішення слідувати теорії такого устрою з трактуванням майже неконтрольованих економічних процесів.

Тому проблеми пошуку шляхів економічного зростання України пов'язані з дослідженням наукових концепцій сутності і змісту фінансово-економічного механізму соціально-економічних систем, застосуванням інституціонального підходу як інструменту ефективного інноваційного розвитку методики обліку макроекономічних резуль- 
татів. Удосконалення управління економічною системою передбачає формування прогресивної структури суспільного виробництва, його інтенсифікацію, збалансування і пропорційний розвиток та ефективний макроекономічний облік і аналіз господарської діяльності. Для виконання цих завдань найважливіше значення має збалансований розвиток економіки, забезпечення пропорційного розвитку всіх галузей господарства та регіонів країни.

Формування нової економічної системи, заснованої на сучасних відносинах, матеріалізація національних цілей через державну економічну політику потребують широкого використання системи економічних показників. Вони покликані відображати складні взаємопов'язані процеси, що відбуваються в економіці й безпосередньо визначають динаміку економічного зростання та важливі пропорції розширеного відтворення сфери господарського механізму країни.

Розрахунки економічних показників та важливих пропорцій розширеного відтворення здійснюються на основі відповідної економічної методології, що відображає річний економічний оборот на національному рівні. Вони є також важливим інституційним інструментом економічного регулювання і прогнозування національної економіки. Країни з ринковою економікою, а також ті, що здійснюють перехід до світових відносин, як таку економічну модель використовують СНР, що затверджена ООН і рекомендована для використання 3 метою забезпечення міжнародних зіставлень та порівнянь.

Економічний механізм країни складають безліч фірм, індивідуальні одиниці господарювання, організації, об'єднання, кооперативи тощо. Щоб дослідити господарський механізм країни, слід «підсумувати» результат діяльності кожної фірми, одиниці господарювання. В економіці таке «підсумовування» називається «агрегуванням». В результаті отримуються дані про кількість товарів і послуг, що виробляються в суспільстві, про сукупні витрати і сукупні доходи усіх економічних суб'єктів, про середній рівень цін тощо. Агрегування дозволяє отримувати статистичні показники, які характеризують сукупне виробництво. Ці дані представляють національні економічні показники.

Проблеми, пов'язані з аналізом функціонування фінансово-економічного механізму, з його результативністю, у багатьох випадках зводяться до єдиної проблеми правильного вибору ключових показників 
діяльності підприємств та їхньої інтеграції у єдину систему. Треба зауважити, що взаємозв'язок між різними показниками повинен здійснюватися лише на рівні інтеграції, а не координації, а зв'язки в організації можуть бути двох видів - на рівні координації і на рівні інтеграції. Це стосується і зв'язків між різними показниками інтегрованої системи.

\section{4. Методика оцінки кінцевих споживчих витрат домогосподарств}

Механізм національного обліку, чітко визначаючи кінцеві споживчі витрати домогосподарств і загальну схему їх розрахунків, не дає точного «рецепту» послідовності їх обчислення. Це, зокрема пояснюється тим, що в різних країнах, як головний, використовується один 3 двох основних методів розрахунків ВВП - виробничий або кінцевого використання. В Україні в основу розрахунків ВВП покладено виробничий метод, особливо це стосується помісячних розрахунків. Звідси випливає досить складна і непряма «технологія» визначення кінцевих споживчих витрат домогосподарств у ВВП - від його виробництва, далі через розподіл та перерозподіл до кінцевого використання. Певний вплив на методику розрахунків цього компоненту ВВП мають стан та особливості національної статистики, наявність і деталізація необхідних статистичних даних, їх відповідність вимогам щодо оцінки окремих складових ВВП. Проте, такий напрям їх розрахунків не гарантує від можливих неточностей. Він програє їх безпосередньому прямому визначенню, яке також не забезпечує високої точності розрахунків

Визначення кінцевих споживчих витрат домогосподарств здійснюється послідовно.

Першим кроком розрахунків за виробничим методом $є$ визначення загального обсягу ВВП на рахунку виробничтва товарів та послуг. За цим рахунком загальна величина валового випуску всіх галузей економіки (видів економічної діяльності) у ринкових цінах зменшується на величину проміжного споживання і таким чином визначається обсяг ВВП у ринкових цінах (табл. 1).

До подальшого розгляду методики розрахунків кінцевих споживчих витрат домогосподарств у ВВП доцільно коротко зупинитись на двох питаннях, які тісно пов'язані з ними. Це терміни їх розробки та галузева деталізація. 
Таблиця 1

Валовий випуск, проміжне споживання та ВВП в Україні

\begin{tabular}{|c|c|c|c|c|}
\hline Роки & $\begin{array}{c}\text { Валовий випуск } \\
\text { (у ринкових } \\
\text { цінах) }\end{array}$ & $\begin{array}{c}\text { Проміжне } \\
\text { споживання }\end{array}$ & $\begin{array}{c}\text { ВВП (у } \\
\text { ринкових } \\
\text { цінах) }\end{array}$ & $\begin{array}{c}\text { Частка ВВП } \\
\text { (\%) у валовому } \\
\text { випуску }\end{array}$ \\
\hline $\mathbf{A}$ & $\mathbf{1}$ & $\mathbf{2}$ & $\mathbf{3}$ & $\mathbf{4}$ \\
\hline 2005 & 1256345 & 1231178 & 25957 & 48,4 \\
\hline 2006 & 1434632 & 1321333 & 30330 & 47,3 \\
\hline 2007 & 1511157 & 126124 & 33506 & 45,1 \\
\hline 2008 & 2377522 & 229249 & 60496 & 39,3 \\
\hline 2009 & 2858702 & 1654933 & 67902 & 42,1 \\
\hline 2010 & 13108480 & 7656838 & 317396 & 41,3 \\
\hline 2011 & 10185390 & 103871 & 231486 & 44,0 \\
\hline 2012 & 11216719 & 123354 & 258449 & 43,1 \\
\hline 2013 & 11236515 & 133711 & 258905 & 43,4 \\
\hline 2014 & 1298223 & 167781 & 29707 & 43,7 \\
\hline 2015 & 399701 & 129631 & 9404 & 42,5 \\
\hline 2016 & 484220 & 80030 & 11474 & 42,2 \\
\hline 2017 & 513860 & 92928 & 11950 & 43,0 \\
\hline
\end{tabular}

Джерело: [4, с. 12; 5, с. 13]

Остаточні розрахунки ВВП дуже складні, вони передбачають використання даних майже всіх «галузевих» статистик, зведеного бюджету, зовнішньої торгівлі і платіжного балансу, численних оцінок, балансування тощо. Причому, тут йдеться не лише про необхідність отримання остаточних даних у фактичних цінах, а й у цінах попереднього року, тобто змін фізичних обсягів ВВП і його компонентів до попереднього року. Це значно ускладнює розрахунки i ïx балансування за трьома методами визначення ВВП. А щодо перших, попередніх розрахунків ВВП і його основних складових, включаючи кінцеві споживчі витрати домогосподарств, то Держкомстат України здійснює ці оцінки досить швидко вже через півтора місяця після закінчення поточного року - у середині лютого наступного року. Проте у попередніх розрахунках подається лише загальна величина кінцевих споживчих витрат домогосподарств без наведення окремих рахунків, які оприлюднюються з остаточними даними і які показують процес формування цих витрат. 
Друге питання пов'язане з розрахунками ВВП за видами економічної діяльності. Як вже відзначалося, в Україні розрахунки ВВП здійснюються виробничим методом. Починаючи з 2005 р. галузеві розрахунки в Україні почали здійснюватись за новою національною класифікацією - «Класифікацією видів економічної діяльності» (КВЕД) [3], яка інтегрована $з$ міжнародними класифікаціями ООН та Свростату. Але перерахунки даних за попередні роки за КВЕДом поки що не зроблені. Це унеможливлює наведення даних за весь період у порівняних цінах.

Найбільш вагомими секторами, в яких в Україні утворюється ВВП (2015 р.) є (рис. 1): обробна промисловість (19,7\%), сільське, лісове господарство і мисливство (16,3\%), транспорт $(13,6 \%)$, оптова і роздрібна торгівля та послуги з ремонту $(12,4 \%)$, операції з нерухомістю $(7,0 \%)$, та виробництво і розподіл електроенергії, газу і води $(6,2 \%)$. На ці шість галузей (видів економічної діяльності) припадало більше ніж три чверті $(75,2 \%)$ виробництва ВВП [5, с. 40].
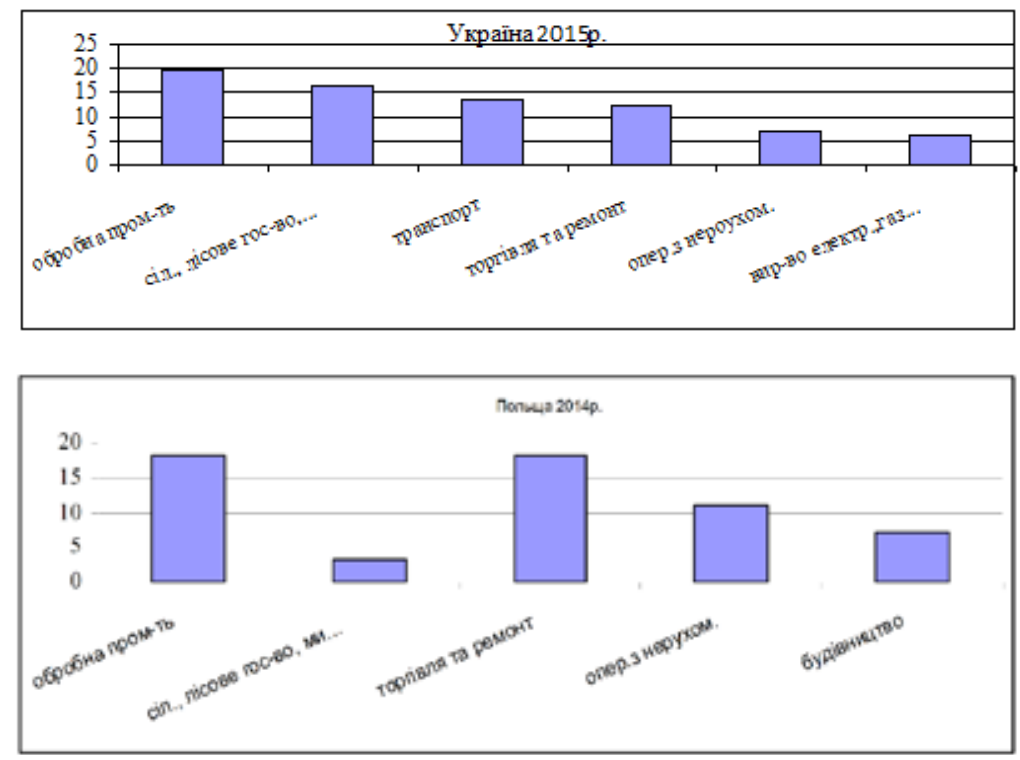

Рис. 1. Структура виробництва ВВП за видами економічної діяльності в Україні 2015 р. та Польщі у 2016 р., \% 
У сусідній з Україною Польщі секторальна структура виробництва ВВП значно відрізняється. Найкрупнішими секторами (2016 р.) були (див. рис. 1): торгівля і ремонті роботи (18,3\%), яка навіть перевищувала обробну промисловість $(18,1 \%)$, операції з нерухомістю $(11,0 \%)$, будівництво (7,3\%). А на сільське, лісове господарство і мисливство припадало лише 3,3\% ВВП [6, s. 546].

Щодо розподілу виробництва ВВП за інституційними секторами, то в Україні у 2017 р. більше ніж дві третини ВВП було створено у секторі нефінансових корпорацій (підприємств) - 66,9\%, сектор домашніх господарств посідав друге місце - 16,7\% і сектор загального державного управління третє - 12,2\% (рис. 1). У Польщі значно вище частка домогосподарств в утворенні ВВП - 31,3\% у 2016 р. Нефінансові корпорації створювали 51,8\% і сектор загального державного управління $13,2 \%$ ВВП [6, p. 546].

Таблиця 2

Рахунок утворення доходу в Україні у 2017 р. (млн. грн.)

\begin{tabular}{|c|c|c|c|c|c|c|c|}
\hline & \multirow[b]{2}{*}{ Всього } & \multicolumn{5}{|c|}{ в тому числі інституційні сектори: } & \multirow[b]{2}{*}{$\begin{array}{c}\text { інший } \\
\text { світ }\end{array}$} \\
\hline & & 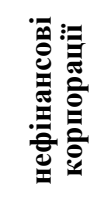 & 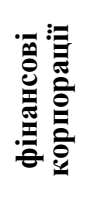 & 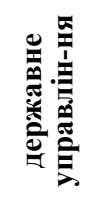 & 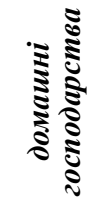 & 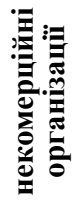 & \\
\hline $\mathbf{A}$ & 1 & 2 & 3 & 4 & 5 & 6 & 7 \\
\hline Ресурси - ВВП & 204190 & 122597 & 5256 & 22314 & 30622 & 2507 & \\
\hline Використання & 204190 & 122597 & 5256 & 22314 & 30622 & 2507 & \\
\hline $\begin{array}{l}\text { Оплата праці } \\
\text { найманих працівників }\end{array}$ & 86440 & 65770 & 2016 & 16767 & 203 & 1684 & 301 \\
\hline \multicolumn{8}{|l|}{ в тому числі: } \\
\hline заробітна плата & 67088 & 51121 & 1531 & 13165 & -1271 & & \\
\hline $\begin{array}{l}\text { фактичні внески } \\
\text { наймачів на соцстрах }\end{array}$ & 18044 & 13471 & 433 & 3528 & 203 & 409 & \\
\hline $\begin{array}{l}\text { умовні внески } \\
\text { наймачів на соцстрах }\end{array}$ & 1308 & 1178 & 52 & 74 & - & 4 & \\
\hline Податки & 29360 & 4968 & 102 & 30 & 517 & 43 & - \\
\hline Субсидії & -2096 & -2070 & - & - & -26 & - & - \\
\hline $\begin{array}{l}\text { Валовий прибуток, } \\
\text { змішаний доход }\end{array}$ & 90486 & 53929 & 3138 & 5517 & 29928 & 780 & - \\
\hline
\end{tabular}

Джерело: [3, с. 64-105] 
Основна частина оплати праці формується в інституційному секторі нефінансових корпорацій, основу якого складають підприємства з випуску товарів і платних послуг (76\% всієї оплати праці у 2017 р.). Причому, 19\% фонду оплати праці створюється у секторі загального держсавного управління (оплата праці працівників бюджетних установ). І близько двох відсотків формується у кожному з секторів фінансових корпорацій (комерційні банки, страхові компаніі) та некомериійних організацій по обслуговуванню домашніх господарств.

Показники валового прибутку та змішаного доходу при утворенні доходу не переглядаються. Процес утворення доходу вимагає розкриття, пояснення термінів, які використовуються в цьому рахунку.

Фактичні внески наймачів на сочіальне страхування включають законодавчо визначені (тобто практично обов'язкові, крім законодавчих виключень) відрахування до Пенсійного фонду та Фонду соціального страхування з тимчасової втрати працездатності (тобто лікарняні виплати), від нещасних випадків на виробництві, професійних захворювань та страхування на випадок безробіття.

Валовий прибуток $i$ змішаний дохід, визначається як балансувальна стаття, тобто як сума, що залишається після виключення з доданої вартості оплати праці і чистих податків. Змішані доходи виникають в некорпоративних підприємствах, тобто підприємствах, в яких виробнича діяльність здійснюється не найманими працівниками, а членами домашнього господарства без оформлення статусу юридичної особи. В них неможливо або важко розподілити цю частину доданої вартості на оплату праці та прибуток.

На рахунку розподілу первинного доходу (табл. 3) здійснюється розподіл утвореного доходу. Тут увага фокусується переважно на інституційному секторі домашніх господарств. Крім 29928 млн. грн., які були створені в цьому секторі в процесі утворення доходу при його первинному розподілі, в нього переходять 86741 млн. грн. у вигляді валової оплати праці найманих робітників з нарахуваннями, які були одержані ними в інших інституційних секторах при утворенні їх доходів. Крім того, ще 4275 млн. грн. у вигляді доходів від власності формують третій елемент первинних доходів домогосподарств, з них 1173 млн. грн. - проценти, 1561 млн. - дивіденди і 1541 млн. грн. - земельна рента. 
Таким чином, доходи інституційного сектору домогосподарств на стадії розподілу первинного доходу складаються з валової оплати праці найманих працівників (з фактичними і умовними внесками на соцстрахування) - 71,7\%, змішаного доходу, створеного самими домашніми господарствами - 24,8\% і дуже незначної частки доходів від власності (доходів від капіталу і землі) - 3,5\%. Для порівняння у Польщі в 2016 р. аналогічні показники формували: змішаний доход - 32,6\%, зарплата найманих працівників - 49,4\%, соціальні внески - 8,6\% (разом валова оплата праці з соціальними нарахуваннями - 58,0\%) і значно більша частка доходів від власності - 9,4\%, та інше - 8,6\% [6, p. 560].

Таблиця 3

\section{Рахунок первинного розподілу доходу України} в 2017 році (млн. грн.)

\begin{tabular}{|c|c|c|c|c|c|c|c|}
\hline & \multirow[b]{2}{*}{2015} & \multicolumn{5}{|c|}{ в тому числі інституційні сектори: } & \multirow[b]{2}{*}{ 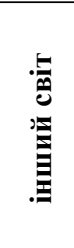 } \\
\hline & & 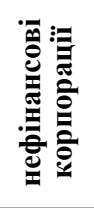 & 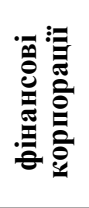 & 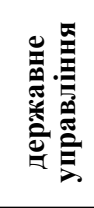 & 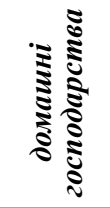 & 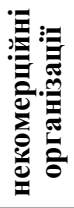 & \\
\hline $\mathbf{A}$ & 1 & 2 & 3 & 4 & 5 & 6 & 7 \\
\hline $\begin{array}{l}\text { Ресурси - валовий } \\
\text { прибуток, змішаний дохід }\end{array}$ & $93292 *$ & 53929 & 3138 & 5517 & 29928 & 780 & - \\
\hline оплата праці & 86741 & - & - & - & 86741 & - & - \\
\hline $\begin{array}{l}\text { податки на виробництво } \\
\text { та імпорт }\end{array}$ & 30720 & - & - & 30720 & - & - & - \\
\hline $\begin{array}{l}\text { субсидії на виробництво } \\
\text { та імпорт }\end{array}$ & -3456 & - & - & -3456 & - & - & - \\
\hline дохід від власності & 19422 & 591 & 7715 & 2370 & 4275 & 13 & 4478 \\
\hline кориг. фін посеред & -2806 & - & -2806 & - & - & - & - \\
\hline Всього ресурси & 219455 & 54520 & 8047 & 35151 & 120944 & 793 & - \\
\hline Використання & 219455 & 54520 & 8047 & 35151 & 120944 & 793 & - \\
\hline Дохід від власності & $19442 *$ & 10858 & 3763 & 4034 & 190 & - & 597 \\
\hline $\begin{array}{l}\text { Валове сальдо первинних } \\
\text { доходів }\end{array}$ & 200610 & 43662 & 4284 & 31117 & 120754 & 793 & - \\
\hline
\end{tabular}

Джерело: [3, с. 64-105]

*/ В тому числі 2806 млн. грн. - послуги фінансових посередників **/ В тому числі 597 млн. грн. - інший світ 


\section{5. Висновки}

Кінцеві споживчі витрати домашніх господарств - один з елементів ВВП за категоріями кінцевого використання.

В Україні, як і в інших країнах світу, це найбільша за величиною частина ВВП. За період між 2007 та 2013 рр. вона коливалась між $44,3 \%$ у 2014 р. та 56,9\% у 2015 р. У 2017 р. ці витрати складали $54,3 \%$ ВВП.

У дослідженні підкреслюється, що кінцеві споживчі витрати домогосподарств (в т.ч. і на одну особу) $є$ найбільш узагальнюючою характеристикою життєвого рівня населення. Вони не обмежуються лише показником доходів у формі заробітної плати (як номінальної, так і реальної), який найчастіше використовується офіційною статистикою України як показник життєвого рівня, а охоплюють і всі інші види доходів домогосподарств у грошовій і натуральній формі.

У роботі обгрунтовані пропозиції враховувати як окремі домогосподарства студентів, які під час навчального року мешкають окремо від батьків (у гуртожитках, або орендують житло) і тому вимушені самостійно вести господарство (витрачати ресурси, в тому числі окремо харчуватися). В Україні їх чисельність становить 430 тис. осіб (або близько 1\% всього населення). Але у вибірковому обстеженні домогосподарств вони не розглядаються як окреме домогосподарство. В той час, як при Всеукраїнському переписі населення 2011 р. вони враховувались як окреме домогосподарство. I тільки починаючи 3 січня 2014 р. - вони почали враховуватися Держкомстатом України.

Оскільки в Україні як основний використовується виробничий метод розрахунків ВВП (особливо щодо щомісячних, квартальних і попередніх річних оцінок), в роботі на прикладі даних ВВП за 2017 рік, показано процес формування кінцевих споживчих витрат домогосподарств. Він послідовно охоплює рахунок утворення доходу, далі рахунки його первинного і вторинного розподілу i, нарешті, рахунок використання наявного доходу. В цьому дослідженні наводяться порівняння формування кінцевих споживчих витрат в Україні і в Польщі, яка досягла значних успіхів у ринкових перетвореннях і 3 травня 2004 р. є членом Свросоюзу. 


\section{Список літератури:}

1. Боровик О.В. Методологічні аспекти функціонування національної економіки і національного ринку. Економічний вісник. 2018. № 1. С. 62-68.

2. Меламед М.Я. Структура ВВП за категоріями доходу і критерії структурної політики. Вісник НБУ. 2017. № 2. С. 9-18.

3. Національні рахунки України за 2017 рік. Стат. збірник. Київ : Держкомстат України, 2017. С. 17.

4. Статистичний щорічник України за 2017 рік. Консультант. 2017. С. 663.

5. System of National Accounts 2016. Commission of the European Communities International Monetary Fund, Organization for Economic Cooperation and Development, United Nations, World Bank. Brussels, Luxembourg, New York, Paris, Washington, D.C., p. 710.

6. Rocznik Statystyczny Rzeczypospolitej Polskiej, 2014. GUS. Warszawa, 2014. P. 546-563.

\section{References:}

1. Borovik O.V. (2018). Metodologicheskie aspekti funksionirovania nasionalnoi ekonomiki i nasionalnogo rinku [Methodological aspects of the functioning of the national economy and national market]. Economic Bulletin, vol. 1, pp. 62-68.

2. Melamed M.A. (2017). Structura VVP za kategoriamy dohodu i kriterii strukturnoi politiki [Structura VVP za kategoriamy dohodu i kriterii strukturnoi politiki]. Visnik $N B U$, vol. 2, pp. 9-18.

3. Statistighniy zbirnik (2017). Nationalny rahunki Ukraini [Nationalny rahunki Ukraini]. Kiev: Derghcomstat.

4. Konsultant (2017). Statistichniy schorichnik Ukraini [Statistichniy schorichnik Ukraini].

5. System of National Accounts (2016). Commission of the European Communities International Monetary Fund, Organization for Economic Cooperation and Development, United Nations, World Bank. Brussels, Luxembourg, New York, Paris, Washington, D.C., p. 710.

6. Rocznik Statystyczny Rzeczypospolitej Polskiej, 2014. GUS. Warszawa, pp. 546-563. 